\title{
Social fields and natural systems: integrating knowledge about society and nature
}

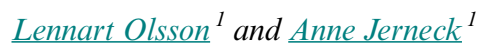

\begin{abstract}
Sustainability science is a wide and integrative scientific field. It embraces both complementary and contradictory approaches and perspectives for dealing with newer sustainability challenges in the context of old and persistent social problems. In this article we suggest a combined approach called social fields and natural systems. It builds on field theory and systems thinking and can assist sustainability scientists and others in integrating the best available knowledge from the natural sciences with that from the social sciences. The approach is preferable, we argue, to the various scientific efforts to integrate theories and frameworks that are rooted in incompatible ontologies and epistemologies. In that respect, this article is a critique of approaches that take the integration of the social and natural sciences for granted. At the same time it is an attempt to build a promising alternative. The theoretical and methodological pluralism that we suggest here, holistic pluralism, is one way to overcome incommensurability between the natural and the social sciences while avoiding functionalism, technological and environmental determinism, and over-reliance on rational choice theory. In addition, it is a basis for generating better understandings and problem solving capacity for sustainability challenges.
\end{abstract}

We make three contributions. First, we identify important reasons for the incommensurability between the social and natural sciences, and propose remedies for overcoming some of the difficulties in integrative research. Second, we show how sustainability science will benefit from drawing more deeply on - and thus more adequately incorporate - social science understandings of society and the social, including field theory. Third, we illustrate the suggested approach of social fields and natural systems in two examples that are highly relevant for both sustainability science and sustainability itself, one on climate change adaptation and one on geoengineering.

Key Words: knowledge integration; methodology; social theory; sustainability

\section{INTRODUCTION: THE NEED FOR INTEGRATION}

The fact that sustainability science is "dealing with interconnected problems" (Kauffman and Arico 2014:413) requires that researchers in the field take a comprehensive, integrated, and participatory approach to science and reality (Sala et al. 2013). This explicit ambition to integrate knowledge - across scales, sectors, and substance domains, and across the nature-society, science-society, and knowledge-action divides-implies that sustainability science must inherently live up to (at least) three things. It must build on several foundational disciplines and have the capacity for interdisciplinarity; it must embrace theoretical and methodological pluralism and have the capacity for reflexivity (Isgren et al. 2017); and it must integrate knowledge generated from engaging with different disciplines, theories, methods, and contexts, and thus aspire to transdisciplinarity. Rather than merging or unifying the actual disciplines or their theories and methods into integrated frameworks, we argue that pluralism is the best way forward for dealing with sustainability challenges, such as biodiversity loss, climate change, land use change, water scarcity, and ill health. In this article, we use ontological, epistemological, and theoretical reasoning to support our argument. The critical ambition is to provide the rationale for a new approach that has the potential to capture the best available knowledge on social and natural dimensions of sustainability; we call it social fields and natural systems. The problem-solving ambition is to describe the approach and illustrate it in two empirical examples. If successful, this will show how holistic pluralism is one possible way of integrating knowledge across the social and natural science divide.

Further down, we will return in more detail to field theory. At its core, it is an integrated social science theory recognizing the complexity of the social world and the processes that contribute to either stabilize or destabilize it. It proposes that strategic action fields are the structural building blocks of political and organizational life in civil society, the economy, and the state (Fligstein and McAdam 2012) and as such they are "the fundamental units of collective action" (Fligstein and McAdam 2012:9). The theory gives due attention to how actors who are embedded in the strategic action fields employ social skills to create, maintain, or disrupt a given field (Fligstein and McAdam 2012). To better understand interaction, interdependence, and the power dynamics within and between strategic action fields, we need to combine different strands of theory. For that, field theory draws mainly on sociological theory deemed to be possible to blend: Bourdieu's (1986) account of capital, field, and habitus; Gidden's structuration theory (Giddens 1979); institutional theory; social movement theory; and symbolic interactionism (Fligstein and McAdam 2012). Taken together, they respond to the main question asked in field theory: who creates new fields, how is it done, and for what purpose?

As shown in other articles in this Special Feature, see for example (Hornborg, Persson, Olsson, and Thorén, unpublished manuscript), it is difficult to integrate scientific knowledge from the natural and social sciences, and it is even harder to do so in ways that do justice to the conditions and principles that are central to each domain (see also Rosa 1998, Carolan 2005a). Perhaps the most successful attempt to bridge two key, but very different, natural scientific and social scientific fields is the case of ecological economics. But even this happens at the expense of reducing society to economics and ecology, to stock and flow models (Hornborg, Persson, Olsson, and Thorén, unpublished manuscript). The dominant attempt to study society and nature in a joint framework is through social-ecological systems (SES), which are conceptually closely associated with resilience thinking. 
Its use in scholarly work has spread rapidly and widely. In tandem with neoliberal thinking, the idea of resilience has been mainstreamed into almost every corner of society (Fainstein 2015, Tierney 2015, Mykhnenko 2016). Studies of social ecological systems (SES) are inclined to elaborate on the ecological implications of social activity and phenomena, while simultaneously reducing the social realm, often to governance and management (Berkes et al. 2000, Walker et al. 2004). But studies oriented toward management and practices in, for example, agriculture, forestry, or fisheries, are often void of considerations of their social context in terms of interest, rights, and responsibilities. Researchers who claim that ecosystems and social systems can be modelled as one coupled social-ecological system thereby risk becoming subject to what we call "holistic reductionism." This means that by incorporating more and more aspects of a problem into the analysis in an overly reductive way either the problem itself, aspects thereof, or both, run the risk of being simplified or trivialized. As a result, this can mean a clustering of things that are contradictory and/or need very different theories to be described, understood, and explained.

In particular, SES scholars have difficulties in dealing with scales and social dynamics (Cumming et al. 2006) such as power (Cote and Nightingale 2012). Social-ecological systems also have difficulties accounting for class, gender, race, and other identitybased analytical categories and their intersections, which tend to be incorporated more in terms of mere head counts, for example, women/men, than in terms of power-based understandings of social processes such as discrimination, exclusion, inequality, marginalization, or oppression. Similarly, soil science tends to be reduced to simple categories like sandy soils or clayey soils, whereas ecosystems tend to be reduced to storage of carbon. Some resilience scholars even elevate "holistic reductionism" into a general rule:

Critical changes in social-ecological systems are determined by a small set of three to five key variables, i.e., the "rule of hand." To understand change in systems, it is important to identify this small set (Walker et al. 2006).

This rule may hold true for pure ecosystems, but it is hard to imagine how social dynamics, including the social, the political, and the economic, can be reduced to a few "key variables." Furthermore, it would be even harder to obtain agreement on defining these key variables across ideological and theoretical divides in the social sciences.

To break with cognitive distortion, simplification, or even trivialization, we therefore recommend an approach that allows complexity and "holistic pluralism" (Peterson 1979). It will help us account for empirically fuller issues, historically longer views, and theoretically wider perspectives by placing "rich diversity" and "interdependence" at its core (Peterson 1979). In practice, it implies that researchers, in this case sustainability scientists, must make meaningful efforts to harness the best available knowledge from two or more disciplines in the hope of reaching a thorough understanding of a multifaceted problem that spans several domains. We define best available knowledge as a concept akin to best practices in environmental regulation (Christmann 2000). What counts as the best available knowledge should be determined on a case-by-case basis and in accordance with relevant research fronts. For example, in the case of climate change, the assessments made by the Intergovernmental Panel on Climate Change (IPCC) can be a source of best available knowledge.

\section{ONTOLOGY: ON REALITY AND SYSTEMS}

Ontology is concerned with assumptions, claims, and questions about what exists in the world, how reality presents itself, and to what extent that reality is observable. What exists may depend on the perspective we proceed from (Sankey 2000). Differences in ontology and epistemology are an obstacle to knowledge integration across the boundaries of scientific disciplines (Rosa 1998, Sankey 2000, Carolan 2005a, Jerneck et al. 2011). In sustainability science a key challenge to knowledge integration is how to deal with seemingly incompatible assumptions deriving from varied ontological claims in the natural and social sciences (Jerneck and Olsson 2011). A main concern is thus to ensure that the best available social science knowledge is combined with the best available knowledge in natural sciences, medicine, engineering, etc. The question here is how to proceed with that process. Instead of treating nature and society as a whole, as an ontological description of reality, and of what exists, we will treat them (nature and society) analytically apart here, as separate entities or spheres requiring different epistemologies, theories, and methods to be observed, explained, understood, and thus, known.

There are several reasons for making this separation. First, there are decisive ontological divides not only between the natural and social sciences but also within the social sciences. Whereas the realist sees social reality as consisting of enduring phenomena, the constructivist sees social reality as situated and constructed in "the flow of interaction" (Abbott 2004:47). Whereas methodological individualism sees the individual as "the only real entity," emergentism, in contrast to such reductionism, sees social relations and processes as the main entities, and as such, irreducible to combinations of individual action and events (Abbott 2004:45). Second, in the 1950s and 1960s during the height of functionalism, especially in sociology, systems thinking was influential but in contemporary social sciences there are obstacles to systems thinking. Researchers studying social phenomena based on social theory may be reluctant to use systems as an ontological description of society that sees the social as one entity. They may instead decide to use it analytically to study a specific (delineated) aspect or unit of the economy, polity, or society, such as the energy system, the party system, the social security system, the tax system, the transport system, or the family as a system. In his book Development Betrayed, Richard Norgaard (1994) describes the social as composed of four subsystems that are not easily bounded: values, knowledge, organization, and technology. These four subsystems can be said to refer to what Husserl calls "categories of meanings" (as cited in, Thomasson 2016). They represent social aspects that are necessary for explaining and understanding society, and as such they are analytical rather than ontological descriptions. Complementary to this, Husserl speaks of ontological descriptions in terms of "categories of objects" (as cited in, Thomasson 2016). Admittedly, systems thinking does not necessarily lead to invisibility or misunderstandings of the dynamics of the social sphere, but there are many difficulties involved in productively using a SES frame for analyzing the social, many of which we 
have discussed elsewhere (Olsson et al. 2015a). The point here, as we go on to discuss further below, is that by taking the social as a system, as one entity, we will likely underestimate what is going on there in terms of conflicting attitudes, interests, values, and social relations.

\section{Illustrating ontological and scientific distortion}

Systems and system boundaries are core ontological components of the natural sciences, both in theory, such as stock and flow models, and in practice, for describing and quantifying biogeochemical fluxes. But determining system boundaries of social phenomena is problematic because social boundaries are often culturally, legally, or politically fluid and contested. Boundaries can also be subject to scientific disputes, particularly if attempts are made to incorporate social interaction, social processes, and social relations into the analysis of ecosystems (Schlüter et al. 2012). By coalescing nature and society into a common system frame, such as a social-ecological system, we risk misunderstanding not only society but also nature.

Fisheries research is a good illustration of this issue. In the study of marine resources there is a conflict between the ecological understanding of fish populations in oceans and the management understanding of fisheries as a geographically bounded system (Reiss et al. 2009). According to ecologists Ray Hilborn and Carl Walters, fish stocks are arbitrary groups of fish large enough to be essentially self-reproducing with members of each group having similar life history characteristics (Hilborn and Walters 1992). Yet, there is no such thing as a geographical boundary in this ecological definition of stock.

However, when the concept of stocks is used for the purpose of fisheries management, it is practical to create geographic boundaries around stocks. The FAO defines stock as "a sub-set of one species having the same growth and mortality parameters, and inhabiting a particular geographic area" (Sparre and Venema 1998). For demersal fish, e.g., flounder, sole, and turbot, and most crustaceans, e.g., crabs, lobsters, and crayfish, such a definition may be appropriate, but not for migratory fish, such as mackerel or tuna. This shows the contestation between how the stock concept is used in practice as in management and in science as in ecology (Secor 2014). This may lead to a situation where governance considerations interfere with, or even contradict, science.

The current struggle between two different modes of fisheries governance serves to illustrate this distorted scientific understanding (Pauly et al. 2013) even further: either we should strengthen management of all fisheries (Hilborn 2017), if we see fish as migrating, or we should establish large marine protected areas where fishing is banned (Lubchenco and Grorud-Colvert 2015), if we see fish as living in bounded areas. Reasoning within geographically bounded systems may lead to one-dimensional conclusions, as seen in this debate where some ecologists advocate marine protected areas. But if fishing in large swaths of the oceans is banned, it may result in increased destruction of terrestrial ecosystems because of an increased need for other sources of protein (Agardy et al. 2003; Open Communication for the Oceans 2013, https://www.openchannels.org/chat/online-debate-largeno-take-areas-their-total-environmental-impact-positive-or-negative). Thus, when governance scholars apply a natural science framework without proper understanding of underlying ecological principles, they may risk promoting inappropriate or scientifically unfounded political recommendations. In this particular case we also see how the ontological perspective on what exists (here in terms of how fish live and move) matters for how we conceptualize, study, and work toward sustainability. And not only that, the political economy of production, consumption, and distribution will also matter for how decisions are made, as we discuss below.

\section{Ontological differences and depoliticization}

In an attempt to normalize or depoliticize political concepts and processes, neo-liberal politics have borrowed concepts and ideas from systems science (Cooper 2011). Resilience is a favorite concept in neo-liberalism, as indicated by the many references describing the linkages between neo-liberalism and resilience (Jerneck and Olsson 2008, Joseph 2013, Chandler 2014, Cretney and Bond 2014, Anderson 2015, Fainstein 2015, Tierney 2015, Mykhnenko 2016, d'Albergo and Moini 2017, van de Pas et al. 2017, Mckeown and Glenn 2018). It has become so natural to speak in systems terms, such as resilience and self-organization of social ecological systems (Holling 2001) as well as adaptive management in response to climate change, that it can be easy to miss the complex, contradicting, and powerful political forces involved.

However, following Colin Hay (2002:3) "all events, processes and practices which occur within the social sphere have the potential to be political and, hence, to be amenable to political analysis." What makes an analysis political is its focus and emphasis on "the political aspect of social relations" and, in particular, the "attention to the power relations implicated in social relations" (Hay 2002:3). This implies, for example, that distributive issues and the "sociology of structural inequality" are subjects of political analysis (Hay 2002:3). In the context of sustainability it means that socially, spatially, and temporally differentiated drivers of, impacts of, and responses to climate change and other resource challenges must be studied while remembering that politics are concerned with "the distribution, exercise and consequences of power" (Hay 2002:3) and of other material and/ or discursive resources. If not, then we risk putting up blinders against the cultural, political, and social contexts that matter (Rosa 1998). We will return to this idea later.

\section{EPISTEMOLOGY: ON DIVIDES, PLURALISM, AND UNIFICATION}

Epistemology is concerned with assumptions, claims, and questions about how to gain knowledge about the world, how to combine or integrate different types of knowledge, and how to define "who is a knower." As with ontology, there are decisive epistemological divides in the social sciences that must be considered in the effort to integrate knowledge. When economists study individual choice based on preferences and full information, sociologists and feminists may study how and why these same individuals comply with, are constrained by, or challenge existing social norms and relations, and how and why this limits or extends their choice. Obviously, these different entry points, choice or constraint, draw on different theories around acquiring knowledge. There are other important epistemological divides and ambitions within the social sciences. Positivism aims at prediction, generalizability, and universality whereas interpretivism focuses on consciousness, contingency, and contextual meaning- 
making. And although both may seek to understand and explain social relations, positivism is mainly nomological and oriented toward regularity, whereas interpretivism is mainly idiosyncratic and oriented toward the particular, singular, or unique. Further, although some scholars pursue formalized causal analysis, others prioritize narration and storytelling (Abbott 2004).

In this context, we distinguish between two types of scientific knowledge integration: pluralism and unification (Olsson et al. 2015a, Geels et al. 2016). Scientific pluralism is a process wherein several disciplines contribute particular theories, questions, and/ or methods to describe, explain, understand, or solve a problem. According to scientific pluralism, the ultimate goal of scientific inquiry is not (necessarily) to establish a single theory (Kellert et al. 2006). Rather, pluralism is useful in situations where no unified theories are available to explain a phenomenon or where the phenomenon can only be explained through the lens of multiple theories (Dupre 1991, Mitchell 2009). Undoubtedly, this is the situation in the case of a comprehensive context such as that of climate change or geopolitics.

In contrast, unification may easily result in scientific imperialism, a process that is usually thought of as an infringement; often when one discipline attempts to explain phenomena or solve problems in a domain belonging to or associated with another discipline (Dupre 1994, 2001). Whereas Dupre argues against imperialism, Mäki argues that there are situations where scientific imperialism can be useful rather than detrimental (Mäki 2009, 2013). Serious cases of scientific imperialism are reductive in the sense that they aim, or tend, to exclude alternative (even compatible) explanations and solutions (Midgley 1984, Clarke and Walsh 2009, Thorén 2015) resulting in a situation where inferior explanations or problem solutions might outcompete superior ones (Thorén 2015), and thus a situation where the best available knowledge is not used. Unification is not necessarily imperialist (in this negative sense), but there is always reason to worry about imperialism in situations where a single theory (or discipline) claims to account for all aspects of major or persistent social problems such as inequality, poverty, social unrest, and corruption, or for complex phenomena such as geopolitics or climate change including their impacts on society and various responses to them (Hornborg, Persson, Olsson, and Thorén, unpublishedmanuscript). In contrast, in the context of geopolitics, pluralism has not only scientific value, but can also help sustain cultural, ecological, and social diversity (Norgaard 1989). This can be seen in and pursued in research that harnesses both scientific knowledge and knowledge acquired through practical experience, while also seeking to reconcile the two (Agrawal 1995, Parsons et al. 2017; Persson, Johansson, and Olsson, unpublished manuscript). Although pluralism has many merits, and is almost seen as an axiom in sustainability science, it can obviously also lead to unwanted imprecision or conflicts between different theories and concepts that are engaging in similar questions.

\section{THEORY: ON HOW TO CONCEPTUALIZE AND UNDERSTAND THE SOCIAL}

Theory constitutes a main guide for empirical exploration, analysis, and interpretation. It is also a guide to explanation and to transferability between temporal and spatial contexts. It serves to both simplify how we see reality and more fully describe, explain, and understand it in terms that are appropriate for, and also comparable between, different contexts. Further, it can help "tie together past and present" (Burawoy 2009:9). Theory can be descriptive, prescriptive, or predictive and can be used to challenge or confirm stated and unstated assumptions. Theories are characterized by their distinct perspectives and are (often) conceived of and expressed to represent, or even consolidate, a special subject-position or vantage point (Hay 2002). Realms of explanation vary, and theory therefore seeks to (elegantly) turn an object under scrutiny into something recognizable, while posing questions that matter from a given perspective (Abbott 2004). This means that theory is not necessarily neutral, but often imbued by certain interests and values (Cox 1981) and by a suggested direction for social change, or mechanisms for continuity and/or stability. But if theory is said also to be a "condensation of accumulated knowledge," it must be open, preliminary, and subject to continual modification or refinement (Burawoy 2009:9).

Inspired by Colin Hay (2002) we will discuss three particular theoretical issues, and, for our purpose here, place them in the context of sustainability research: the role of consensus and conflict theory; the tension between complexity (the world is assumed to be nuanced and can mainly be described concretely and only with some degree of plausibility) and parsimony (the world is assumed to be simple and can be abstracted, explained, and predicted); and finally, the dynamics of agency and structure in society, and how that is tackled in social theory.

\section{Consensus versus conflict}

A crucial source of incommensurability between the social sciences and most natural sciences interested in processes of environmental change, such as degradation, exploitation, pollution, or rehabilitation, is how society and the social are understood (see, for example, Rosa 1998, Carolan 2005a). Sociology identifies two main types of approaches to understand society: consensus theory and conflict theory. One important implication of the complementarity or dualism that the theories espouse, is that environmental governance and management at multiple scales will be executed, manifested, and understood very differently in the two types of theory.

According to consensus theory there are core values, informal norms, and hidden rules in society that serve as a foundational, unifying structure of a stable and harmonious society, wherein social change is slow and orderly. Norms, rules, and values are continually reproduced through culture, and stability is the outcome. This is reflected in the grand social values of functionalism as an aggregate view of society, as well as in microsociological interaction rituals, although symbolic interactionism can allow for both change and continuity. Studies based on a consensus perspective will search for the hidden rules that maintain social stability (Abbott 2004). In coupled socialecological systems, resilience can be seen as the equivalent of stability, harmony, and the "good norm" (Hatt 2013, Olsson et al. 2015a). If society is understood as characterized by negotiations for consensus, scientific evidence and arguments can ostensibly play an important role in decision making.

In contrast, conflict theory proceeds from the stance that there are competing ideas and interests between groups in society, meaning that social order is maintained by (discursive and/or material) agency and control by dominant, privileged, and 
powerful groups, and that transformational change develops from the tensions between these groups, and from the redistribution of power and other resources, between them (Meadowcroft 2011). In conflict theory social relations are imbued by power, and society is defined by deviating interests that create, reproduce, and maintain social differentiation, unequal distribution, and other inequalities. Consequently, institutions are shaped by existing power imbalances and social stratification. Research that proceeds from this perspective will take social conflict as a starting point and seek to reveal its causes, consider its consequences, and, oftentimes, also suggest social change. In doing so, it will search for hidden norms and rules that are "the concealed sources of conflict" (Abbott 2004:50). If society is understood through a conflict lens, the potential for using scientific arguments in decision making is lower.

\section{Illustrating consensus versus conflict}

The theoretical dualism above can be illustrated by the example of a study using the SES framework to examine the global sea food market. The study claims that self-organization of large corporations as key-stone actors in global fisheries can lead to sustainability (Guerry et al. 2015, Österblom et al. 2015). But how can this be the case when transnational corporations often exploit their unique position to avoid or reduce the effects of regulation for the sake of maximizing their own profits and power (Kalfagianni and Fuchs 2015)? Self-organization of large corporations in the name of sustainability is therefore not only highly unlikely but also constitutes an utterly depoliticized approach to sustainability (Olsson et al. 2015b). The claim is therefore questionable, we argue. It builds upon a consensus perspective that disregards conflicting interests in society between profit-making firms, the idea of corporate sustainability, and the vision of sustainable fisheries.

\section{Complexity versus parsimony}

The choice between complexity and parsimony is important in the selection of analytical perspectives and research strategies (Hay 2002). A parsimonious model is as simple as possible but explains as much as possible. However, at some point the merits of parsimony may be outweighed by the benefits of, or need for, greater complexity and detail (Hay 2002). On one side of a spectrum, pure and detailed description may capture real (or full) complexity without explaining much; whereas on the other side, abstract theoretical reasoning may be forceful in explaining and predicting a lot without capturing layers, nuances, or parts and pieces (Hay 2002). From a philosophy of science point of view, simplicity (parsimony) is a virtue (Baker 2016), whereas for the historian and interpretivist, complexity and detail may, in some instances, be of higher priority. However, it is not always straightforward to judge what complexity or parsimony actually mean in a particular case or how to decide on the appropriate level (or degree) of parsimony (Baker 2016).

Seeking to preserve complexity while also capturing a reasonable degree of specificity, constructivist and institutionalist scholars proceed with theory in close dialogue with data, including details, to piece together theoretically informed and empirically grounded historical narratives (Hay 2002). They suggest or establish the preconditions, conditions, and mechanisms of change by studying the interplay between ideas, institutions (including their values), and interests pursued by actors (Meadowcroft 2011). In doing so, they are inclined to acknowledge complexity, identify sequencing, and consider timing, all of which are enabled by methods of process-tracing, process-elucidation, and a general open-ended approach to understanding processes (Hay 2002). In sustainability science, constructivists and institutionalists are prone to locate and analyze political aspects of the environment by considering how to value, prioritize, and sequence different social goals and sustainability pathways. Critical realists in sustainability science, often base their analysis on a wealth of data and tend to use a variety of economic and social theories to delve into the unobservable layers and mechanisms of humanenvironmental dynamics, often in terms of continuity and change (Nastar 2014, Boda 2018, Harnesk 2018).

\section{Illustrating complexity versus parsimony}

This discussion of complexity versus parsimony can be further illustrated using an interesting ecological discussion on sustainability. In an article in 1993, three eminent ecologists refuted the concept of sustainable development or, more precisely, the idea that natural resources can be managed in a sustainable way (Ludwig et al. 1993). They did so by invoking the reductionist claim that overexploitation of resources is a fundamental trait of human behavior, thus implying that the only way to reduce environmental degradation is to reduce the global human population or, in their words, "It is more appropriate to think of resources as managing humans than the converse" (Ludwig et al. 1993:17). In his 1998 book on complexity, Emery Roe (1998) criticized this simplistic view. Instead he defended the concept of sustainable development by embracing complexity in a process of triangulation (Olsen 2004) based on four theoretical approaches: Girardian economics ${ }^{[1]}$, cultural theory, critical theory, and local justice. This attempt to embrace complexity in approaching sustainable development was later criticized by Holling, who suggested that complex interactions in social-ecological systems can be reduced to a few controlling processes (Holling 2001), an argument that was later repeated by Walker et al. (2006) as mentioned in the introduction.

Holling sweepingly dismissed studies that involved many indicators of change (Holling 2001). He argued that systems are self-organized and that the,

complexity of living systems of people and nature
emerges not fromarandomassociation of a large number
of interacting factors rather from a smaller number of
controlling processes (Holling 2001:391).

Further, Holling claimed the following:

If sustainability means anything, it has to do with the small set of critical self-organized variables and the transformations that can occur in them during the evolutionary process of societal development (Holling 2001:391).

This may hold true for natural systems, but in social science research it is generally not advisable to select a few structural determinants of social continuity or change because that would "distort social complexity" (Mann 1986:4). Relevant to this discussion, cultural theory (Douglas and Wildavsky 1983), rooted in constructivism, seeks to accommodate deviating views and values for the sake of reaching clumsy but empirically rooted solutions (Verweij et al. 2006) rather than offering theoretically 
elegant solutions without (enough) empirical anchoring. However, cultural theory is criticized for its failure to make "a clear distinction between the process and the product of socially constructed knowledge" (Rosa 1998:22).

Returning to the natural sciences, there are clear examples of how the concept of self-organizing systems may lead us astray in the search for sustainability. As we will show below, the issue of sustainable fisheries is a telling example of the pitfalls of singling out a few variables as determining of a self-organizing system. To begin with, studies that are overly optimistic about the prospects for making global fisheries sustainable may simply be based on unsubstantiated wishful thinking (Guerry et al. 2015). More importantly though, there are optimistic studies that use a SES framework to observe trends in how firms express and exercise voluntary fishery governance (Österblom et al. 2015). However, that analysis builds on a limited scientific understanding of ocean ecosystem dynamics. As should be clear by now from our reasoning, the use of a narrow frame to examine a complex problem may lead to a situation where researchers end up with a distorted scientific understanding of the problem, here fisheries, and a depoliticized view of governance, here the governance of fisheries, as was discussed earlier. The problem with a narrow frame becomes obvious when a certain perspective on a sustainability issue ignores specific ecological mechanisms that could severely undermine the ecological system, as in this case of the ecology of marine systems. The ecological mechanism would tell us that fisheries can be threatened by an array of conditions such as ocean acidification (Marshall et al. 2017), invasive species (Walsh et al. 2016), microplastics (Cole et al. 2011), or decline in ocean oxygen levels (Schmidtko et al. 2017). Such destructive but gradual impacts on fisheries will lead to declining profits for keystone actors, which may in turn result in changes in their fishery governance and practices. These changes, like in the previous example on key-stone actors, will not necessarily be beneficial for long-term sustainability because large corporations are currently governed more by profit and short-term fluctuations on the stock market than by corporate leadership and sustainability (Cherry and Sneirson 2010).

\section{Agency, behavior, and interaction}

There is a dividing line between social and nonsocial approaches to human behavior and social change. Although some believe in "presumed qualities inherent in individuals" as in individualistic and naturalistic approaches (Jones et al. 2011:1), others focus their attention on the "social dimension of human existence" (Jones et al. 2011:5), thereby underlining the importance of interactions and social relations between individuals, and how these vary between social settings and situational contexts. Another important dividing line in the social sciences is how to define, explain, and understand human agency and behavior, i.e., how we act and perform, the scope and limits of our agency, and the reasons behind why we think, speak, act, and make particular decisions. As a starting point, structuralism, at the one end, tends to reduce social outcomes to the workings of institutions and structures beyond the control of actors and their agency, whereas actor-oriented theories, such as intentionalism (Dessler 1989, Hay 2002), on the other end, tend to account for observable effects in purely agential terms. In structural and structured theory the determining features of society are associated with structures external to the individual and her/his interpretations of society, whereas interactionist theory pays attention to the "capacity for meaningful interaction" and interpretation (Jones et al. 2011:120). According to action theory, society is defined and recreated by social interaction. Here society is not determined by structures, but is instead seen as subject to meaningful interpretation and intentional action.

In rational choice theory, the theory that forms the basis of neoclassical economic theory, individuals make decisions based on the choice to maximize their own utility. The assumption of rational choice provides a reductionist basis for modelling the economy as a self-organizing system. It also provides a scientific justification for the current proliferation of market-based instruments for ecosystem management. This is epitomized by The Economics of Ecosystems and Biodiversity initiative (TEEB) aiming to help decision makers recognize, demonstrate, and capture the values of ecosystem services and biodiversity (Kumar 2010, Brown 2014).

Rational choice theory is widely used, but also contested, in the social sciences. Behavioral economics represents one potential way to partly overcome the problems with rational choice theory (Kahneman and Tversky 2013, Thaler 2016). Sociologists and critical theorists, including critical feminists, have formulated other elaborate theories for explaining agency and social behavior, such as institutional theory, symbolic interactionism, and performativity theory. In institutional theory, scholars stress various aspects of social and economic interactions and relations to explain historical continuity and change, including slow and incremental change (Mahoney 2000, Mahoney and Thelen 2010). In addition to that, discursive institutionalists will focus not only on how we act or interact but also how we think and speak before, or during, action (Schmidt 2008). In even more sharp contrast to rational choice theory, symbolic interactionism focuses on how social relations play out in contextual conditions, situational specifics, and subjective interpretation (Blumer 1986). As examples of action theory, symbolic interactionism stresses outcomes of interaction and interpretation, whereas ethnomethodology stresses processes and modes of interpretation. Such theories are sources of inspiration for the theory on social fields (Fligstein and McAdam 2012) that we will soon delineate.

In addition, sociologist Randall Collins argues that agency is situated in face-to-face interaction and the here-and-now of society (Collins 2004). From the point of view of microsociology he defines the situation and momentary encounters as sites of explanation for understanding individuals, social relations, and society at large. Following from that, the dynamics of the situation, situational causality, becomes the starting point of the analysis where the situation is seen as emergent property (Collins 2004) and, importantly, outcome can thus not be predicted. Local encounters have both agency and structure, where agency is not to be confused by or identified with the individual (Collins 2004) because it is the interaction and the situation that are the focal points of human encounters and agency.

\section{Research strategy and data}

Acquiring and interpreting data involves a series of theoretical and methodological choices. Academic communities unite around research strategies and types of data gathering that distinguish them from others, each with its own merits, be the data collection strategy comparative case research, discourse 
analysis, ethnography, grounded theory, historical narration, or formalization and surveys. But each one also has its limitations that are often revealed when viewed through the lens of another strategy. To overcome certain limitations, we can move heuristically from one research strategy to another to see what it contributes compared to others. Potential gains from this heuristic exercise can be expressed in details, nuances, and meaning-making that capture complexity and contingency or as formalized abstractions, explanations, and generalized patterns (Abbott 2004). Given this cyclical reasoning, of moving from one research strategy (or theory!) to another, interdisciplinary researchers will need to keep in mind that a study can be "too radical for one group while being insufficiently radical for another" (Abbott 2004:111).

Proponents of using indicators and measurables may seek readily observable data, while also seeking regularity and stability in society, whereas those emphasizing the role of values and meaning-making may assume that the social sphere is divided by conflict and interests, and thus seek other types of data, including insight from nontypical settings. Rather than taking regularity as a given and basis for prediction, a constructivist, institutionalist, or critical realist would explore the conditions for and existence of both regularities and irregularities (Hay 2002). In this kind of research, it is obviously important to study tensions and to consider whether social conflict or cooperation, or both, is the norm.

\section{AN INTEGRATIVE FRAMEWORK: SOCIAL FIELDS AND NATURAL SYSTEMS}

Inspired by American and French sociologists, we suggest an analytical framework to overcome ontological differences between the social and natural sciences, and thereby also overcome ontological barriers in sustainability research. A combined approach has the potential to integrate knowledge across the natural and social sciences, and to do so in a new way. For now, we call it social fields and natural systems. It builds on and juxtaposes two explicit ontological assumptions for comparison and contrast, but not for complete integration: social fields and natural systems. With this, our ambition is to avoid both the risk of depoliticizing social ecological issues, as discussed above, and the scientific imperialism associated with unification and the domination of one discipline over another. The main aim becomes then not to integrate the two but to integrate the knowledge generated from each one.

Further, the approach is good for avoiding three common weaknesses in knowledge integration across the natural and social sciences caused by the use of, in particular, three theories seeking to explain social change: environmental determinism, functionalism, and rational choice. These three perspectives often result in a depoliticized (mis)understanding of environmental issues that may lead to a scientific justification of particular policies, such as promoting resilience in the context of climate change adaptation (Wellstead et al. 2017), in forest management (Newton 2016), or in poverty alleviation (Béné et al. 2012). The new approach is good for combining knowledge that can be generated from each of the two domains: the natural environment, which can be described in terms of systems, and the social sphere, which is better described in terms of social fields.
Even if social fields may lend similarities from systems and from institutional logics (Scott 1995), fundamental differences exist. In Earth system science, the fundamental ontological assumption is that the planet is a system. As long as the system is understood in primarily natural science terms such as an ecosystem, this is usually uncontroversial. Proceeding from that idea, some ecologists claim that "ecological and social domains of socialecological systems can be addressed in a common conceptual, theoretical, and modeling framework" (Walker et al. 2006). However, this is a situation where system ontology may come into conflict with ontological assumptions in the social sciences, as discussed above. That clash will imply a loss of significant social scientific knowledge.

\section{The main features of field theory}

Based on empirical studies and theoretical advancement, sociologists argue that field theory has the power to contribute to a deeper understanding of social dynamics, including those surrounding competing economic and political interests. This is how Levi Martin (Martin 2003) sees it:

I make the case that field theory is something quite different that has the potential to yield general but nontrivial insights into questions rightly deemed theoretical and to organize research in a productive fashion. Finally, field theory allows for the rigorous reflexivity that is necessary in all cases in which sociology attempts large-scale political and institutional analyses (Martin 2003:3).

Bourdieu (1977), who had the ambition to understand society at large, was particularly interested in the fields of culture, education, and religion, and defined field as a network of relations among actors and objects and their objective positions (Ritzer 2011). In his studies of social movements, Gamson (1975) introduced the concepts of incumbents and challengers to field theory. Incumbents have disproportionate power in or over a field which, in turn, supports them. In contrast, challengers are less privileged in that field and are either in opposition to, or more often, suppressed by it.

In their study of transnational migration, Levitt and Schiller (2004) applied field theory to highlight and study hidden institutions and social processes, and, importantly, challenged a routine notion of geographical scales:

\section{The concept of social field also calls into question neat divisions of connection into local, national, transnational, and global. In one sense, all are local in that near and distant connections penetrate the daily lives of individuals lived within a locale (Levitt and Schiller 2004:1010).}

The three points made here on field theory - the emphasis on reflexivity; the crucial distinction and interaction between the two main types of actors in the field, the incumbents, and the challengers; and the importance of a taking a multiscalar approach - are all relevant to keep in mind for sustainability scientists in the quest for sustainability.

Fligstein and McAdam (2012), who aim to construct a comprehensive general theory of fields, see strategic action fields 
as representing meso-level social orders and, as such, as the structural base of modern political and organizational life. Identifying these strategic action fields is the starting point for studying stability, continuity, and change in society. In their theory of fields, Fligstein and McAdam (2012) expand the notion of fields to become a (more or less) universal concept for understanding social change and social order. In doing so, they expand the conceptual vocabulary and the horizon for what to study as a field. According to them, social relations exist independently of whether people are aware of them or not, and whether people want them or not, and thus need to be considered. This can be taken as an indication of a critical realist or pragmatist approach, where theory is needed to make sense of that which is actual and real but not necessarily empirically observable.

As an important argument against rational choice explanations of social change within a field, Fligstein and McAdam argue vehemently that "the material and the existential cannot be disentangled" (Fligstein and McAdam 2012:49). Inspired by symbolic interactionism, they stress the importance of social skills, defined as a capacity for intersubjective thought and action in social relations. The concept of social skill is rooted in symbolic interactionism which rests on three main assumptions (Blumer 1986): (a) that individuals act toward things on the basis of the meanings they ascribe to those things, i.e., things have no universal value in themselves; (b) the meaning of such things is derived from, or arises out of, the social interaction that one has with others and with society implying that decisions are primarily relational rather than individual; and (c) these meanings are handled in, and modified or recreated through, an interpretative process used by the individual in dealing with the things s/he encounters.

\section{Strategic action fields: a condensed version}

To expand a little on the views that Fligstein and McAdam (2012) present, a social field is an arena, or space, of power embedded in a wider context of overlapping and interdependent arenas. A field can be characterized by either competition, collaboration, or both, but because every field is dominated by competition and conflict (hierarchy) or collaboration and consensus (coalitions), the dynamics of a field depend on the relative power to produce a cooperative or hierarchical order. In newer and emerging fields there is a certain flexibility because actors, because of dependent interests, are increasingly forced to take one another into account in their actions. With time, activities inside the field are routinized and institutionalized by governance mechanisms and by incumbents who act to stabilize (or control) the field. Nevertheless, the field will be under pressure from those who question things, the challengers, both from the inside and outside, and thus be subject to various social forces. For those reasons, the idea of strategic action fields is a useful framework for understanding social continuity, social change, and conflict.

For practical reasons, Fligstein and McAdam (2012) suggest a stepwise method for studying a strategic action field over time in terms of its emergence, stabilization, and/or transformation. First, define the field: who are the actors (incumbents, challengers), what is at stake, and how are power structures organized, in coalitions or hierarchies? Second, differentiate between emergent, stable, and transforming strategic action fields. Third, assess the main relationships between any given field and outside actors embedded in other fields: what is the role of and interplay with external actors? Fourth, account for the role of social skills and entrepreneurial action in a field: what are the material and discursive resources and tools? Fifth, look out for exogenous shocks, field ruptures, and the onset of contention: what are the threats to the field? Taking these five steps constitutes a first attempt to apply the theory.

\section{ILLUSTRATING SOCIAL FIELDS AND NATURAL SYSTEMS}

Are environmental issues bounded or transboundary? Despite the many benefits of taking a systems view, there are of course limitations and pitfalls. One of the most widely used frameworks for studying sustainable development in coupled social-ecological systems is Elinor Ostrom's institutional framework (Ostrom 2009). We agree that analytically the resource system in her framework is best understood as a system, but we like to suggest that the seven design principles for successful governance of that resource system (Anderies et al. 2004) are better understood as social fields. We will not go into the details of that here, but instead, move on to more detailed discussions about social fields.

The theory of social fields is useful for a variety of reasons. It has been successfully applied to issues that do not follow or respect system boundaries or national borders. The transnational phenomenon of global environmental change and the various associated issues can be studied as social fields. To take a specific example, we could suggest a study on transnational mobility and how migrants build new livelihoods and communities while often maintaining links with their communities of origin in another country. When applied to human-environmental issues, social fields can facilitate the study of environmental change as a multiscalar, transboundary phenomenon without ignoring the dynamics of interaction and interdependence or confining it to either local, national, or global politics. Further, the notion of transnational social fields has helped avoid methodological nationalism that conflates society with the nation-state (Schiller et al. 1992, Schiller 2005).

Within the frame of social fields, concepts bounded by national borders such as jurisdictions and things determined by them, as well as concepts associated with system boundaries such as community, citizenship, and immigrant, or processes such as assimilation and integration, can be better understood and more effectively resisted or renegotiated (Goldring 1998). In the same vein, livelihoods emerging as a result of urban or rural migration, i.e., the ruralization of the urban and the urbanization of the rural, can be studied as hybrids within the frame of social fields rather than as bounded by a distinction between rural and urban systems. Social fields can also be applied to investigate how and to what extent renting land, as opposed to owning it, is a barrier to the adoption of sustainable agricultural practices in the U.S. (Carolan 2005b).

We illustrate our reasoning in two types of examples. The first example serves to illustrate the use of social fields and natural systems more fully. The second example serves to show the emergence of a strategic action field within the debate on climate change.

In the first example, we examine a case concerned with adaptation to current and future impacts of climate change. It shows how a 
bounded system, a river basin, interacts with unbounded social fields. Importantly, we see how an ontological definition of the natural system, i.e., the river basin, is clashing with the social fields associated with the issue of adapting to floods and droughts. The second example, geoengineering, serves to illustrate more fully how we can apply field theory to a significant case. Here we apply the steps suggested above by Fligstein and McAdam (2012).

\section{A: Climate change adaptation in river basins}

The frequency and severity of climatic extremes have increased in recent years as a result of climate change (IPCC 2012). Many of these events are associated with huge losses of people, livelihoods, and property (Olsson et al. 2014), and also with displacement and sometimes migration (Ionesco et al. 2016). Social responses to climate impacts are diverse and complex, and do not follow any particular boundaries or simple cause-effect patterns. Adaptation is a suitable object of study for our suggested approach, and adaptation studies provide an example of how an understanding and use of multiple ontologies, fields, and systems, can facilitate and promote the production of actionable knowledge in response to climate change.

To take a specific example, a climatic event may affect a clearly defined geographical area. In the case of a flood or a drought the impact is usually defined by the river basin affected, thus a hydrological system. From a hydrological point of view it makes sense to use the river basin as the system boundaries. The vast river basins of the Indus and the Brahmaputra are pertinent examples. They are highly susceptible to climate change impacts in terms of changing precipitation and melting glaciers in the Himalayas, a phenomenon that has implications on agricultural practices and the food security of 60 million people (Immerzeel et al. 2010, Khan et al. 2011). In 2010, Pakistan was hit by its worst natural disaster ever, a flood in the Indus River that put one-fifth of the entire country under water, killing about 1600 people, and costing US $\$ 10$ billion in recovery. The flood was caused by unusually heavy monsoon rains which can, at least partly, be attributed to climate change (Mann et al. 2017), hence a case of adaptation to climate change.

Using hydrological process models, e.g. SWAT, MIKE_SHE, or TOPMODEL (Devia et al. 2015), the extent and severity of floods and droughts can be understood and predicted with great accuracy both in space and time (Khan et al. 2011, Rajbhandari et al. 2015). But neither social repercussions nor social drivers follow these natural system boundaries. The increasing frequency and intensity of floods and drought, as a consequence of climate change (Mann et al. 2017) in combination with social drivers, can be analyzed through interacting systems for the natural science aspects (represented by a hydrological model) and strategic action fields for the social aspects (represented by climate politics in horizontally and vertically interacting fields). Some of these fields are interrelated and some interact directly with systems components.

In Figure 1, we show how some social fields interact directly with place-based phenomena, such as displacement or resettlement of people, and loss of property, livelihoods, and lives. It also shows how certain components of the hydrological system, such as vegetation cover, may themselves be affected by social fields.

Above, we stressed that studying mobility as a social field will challenge notions of geographical scales (Levitt and Schiller
2004). Mobility is a common way to cope with and adapt to an immediate stress such as floods or to escape out of a geographically bounded system. Labor migration can also be understood as adaptation to the more gradual processes of deteriorating livelihoods (Banerjee et al. 2011, Gioli et al. 2014) and would be seen as a social field linking different geographical locations and resulting in myriad interactions. Below, we take another, more discursive, example, to illustrate how powerful forces align their interests and unite to support a particular issue within the realm of climate change.

\section{B: Geoengineering: an illustration of social fields and natural systems}

The central aim of the Paris Agreement "is to strengthen the global response to the threat of climate change by keeping a global temperature rise this century well below 2 degrees Celsius above pre-industrial levels and to pursue efforts to limit the temperature increase even further to $1.5^{\circ} \mathrm{C}$ " (UNFCCC 2015:Article 2). This ambitious target in the context of insufficient national mitigation commitments (Rogelj et al. 2016) makes geoengineering seem inevitable (Horton et al. 2016). In contemporary climate science, scholars discuss two fundamentally different approaches to geoengineering: reducing the amount of solar radiation reaching the Earth, Solar Radiation Management (SRM) versus removing $\mathrm{CO}_{2}$ from the atmosphere into long-term storage in the geosphere or in oceans, Carbon Dioxide Removal (CDR; Vaughan and Lenton 2011). A vast majority of mitigation scenarios for $2{ }^{\circ} \mathrm{C}$ and all scenarios for $1.5^{\circ} \mathrm{C}$ are now based on massive deployment of negative emission technologies, notably bioenergy combined with carbon capture and storage (BECCS) (Rogelj et al. 2015, Schleussner et al. 2016), thus examples of CDR.

The phenomenon that we today call geoengineering, to deliberately alter the global climate system in order to alleviate the impacts of climate change (Allwood et al. 2014), has old roots. Geoengineering has been considered at least since Homer's Odyssey in the late 8th century BC or Shakespeare's The Tempest in 1611 (Schneider 2001). In 1997, in reaction to the increasing demands for emission reductions under the Kyoto Protocol, the physicist (and architect of the H-Bomb) Edward Teller published an article in the Wall Street Journal where he promoted geoengineering under the title "The planet needs a sunscreen" (Teller 1997).

Until recently, geoengineering was peripheral to climate science and the climate change debate. But outside of scientific discussions, several think tanks, lobby groups, and other interest groups associated with the fossil fuel industry, such as the American Enterprise Institute (Union of Concerned Scientists 2017) have used their political influence to promote SRM as a cost-effective alternative to reducing the emissions from fossil fuel (Lane 2009). The argument that these challengers make is entirely economic, exemplified by a report from the Copenhagen Consensus think tank that inquired into the benefit/cost ratios of two SRM technologies: 21-56 for injection of aerosols, and 2400-15,000 for manipulating the albedo of clouds (Bickel and Lane 2009).

Importantly, geoengineering was neither considered a realistic nor desirable option in the climate discourse until 2006 when the Nobel laureate Paul Crutzen stirred up a controversy by discussing the possibility of manipulating the Earth's radiation balance using SRM as a means of solving the "policy dilemma" 
Fig. 1. A stylized picture of how social fields (orange ovals) interact with geographically bounded components of a hydrological system (boxes and arrows) within the boundaries of the Indus river basin (thick black line).

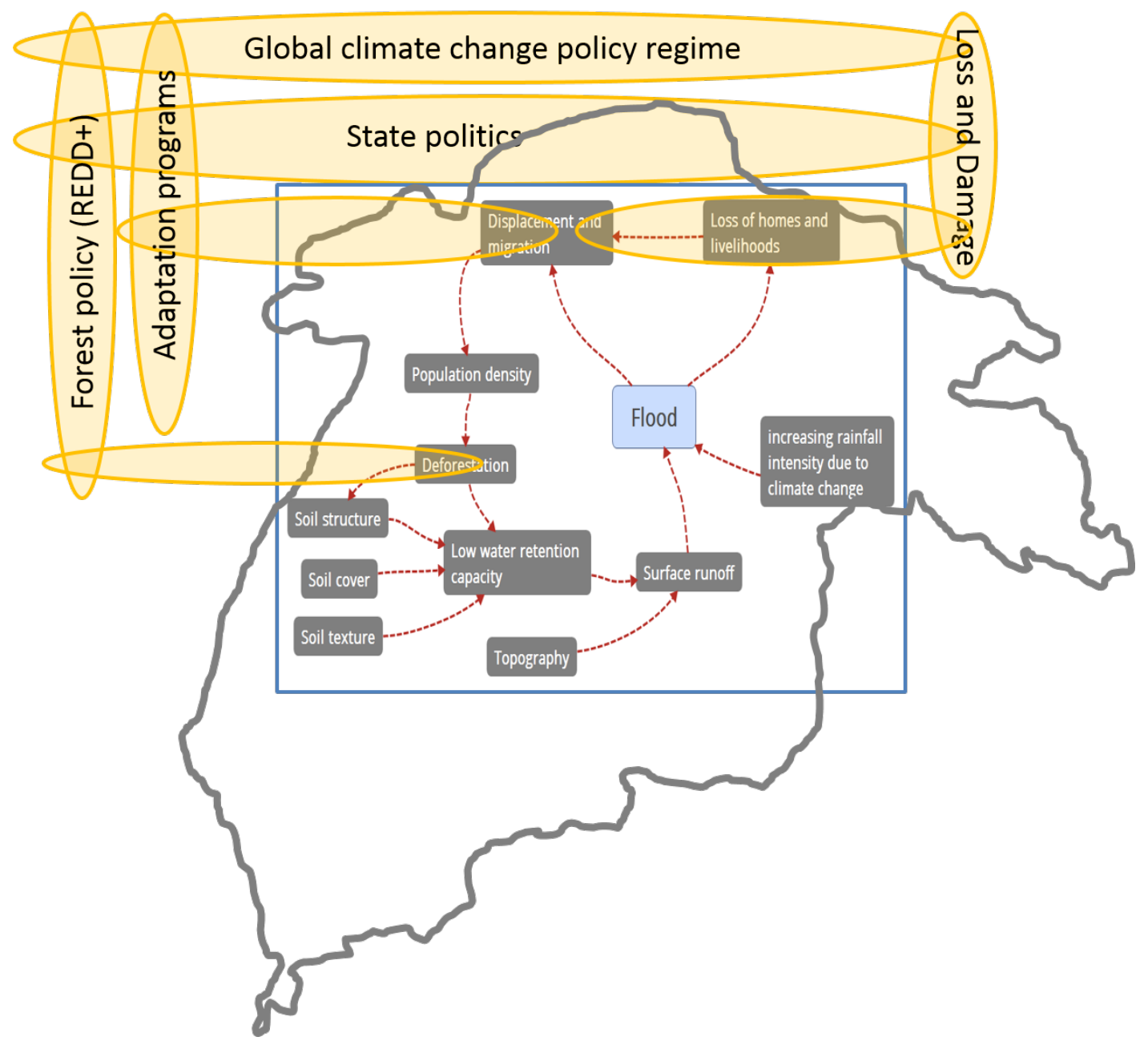

(Crutzen 2006). Crutzen described the dilemma of how reducing the burning of fossil fuel as a means of lowering the emission of $\mathrm{CO}_{2}$ would also reduce the cooling from sulphur dioxide. The solution he described was to deliberately inject aerosols into the atmosphere. He ended his essay by saying the following:

The very best would be if emissions of the greenhouse gases could be reduced so much that the stratospheric sulphur release experiment would not need to take place. Currently, this looks like a pious wish (Crutzen 2006:217).

What Crutzen did not realize was that by publishing the essay he probably made a reduction in greenhouse gas emissions (even) less plausible because just the perception of geoengineering as a viable option reduces the willingness to curb $\mathrm{CO}_{2}$ emissions (Faran and Olsson 2018). From a natural systems point of view, his reasoning makes sense; if we cannot reduce global warming by curbing the emission of greenhouse gases, then we should at least try to counteract the warming by injecting aerosols. But if we apply a social field analysis, we come to another conclusion after considering the broader political implications. By initiating a debate on geoengineering that suddenly became very lively (the essay is cited about 1100 times), Paul Crutzen (willingly or unwillingly) became part of the geoengineering discourse aimed at diminishing the will to curb greenhouse gas emissions. In Figure 2 and Table 1, we illustrate how different strategic action fields interact with each other and potentially with the Earth system itself. Inspired by Fligstein and McAdam (2012) we ask, who creates new fields, how is it done, and for what purpose? At its core, this comprehensive question focuses on, where is the power, what are the tactics, and what is at stake?

Importantly, Crutzen's reasoning about the Earth system offered a serious option for scientists, economists, and policy makers of geoengineering to address climate change from this particular angle. Thereby, we argue, he initiated a new strategic action field, which we call the geoengineering field. Further, we argue that it was not so much the message that counted, because similar views had been expressed before, but the messenger. Paul Crutzen was considered an environmental hero, as one of three scientists and 
Table 1. Summary of strategic action fields in the case of geoengineering (numbers refer to Figure 2).

\begin{tabular}{|c|c|c|c|c|c|}
\hline & CC policy regime (1) & $\begin{array}{l}\text { Climate science } \\
(2)\end{array}$ & Fossil fuel interests (3) & Geoengineering (4) & CC denialism (5) \\
\hline $\begin{array}{l}\text { Who are the actors? } \\
\text { incumbents, } \\
\text { challengers }\end{array}$ & $\begin{array}{l}\text { United Nations, the } \\
\text { UNFCCC parties, } \\
\text { international } \\
\text { organisations (e.g. } \\
\text { World Bank), BINGOs }\end{array}$ & $\begin{array}{l}\text { Science, environmental } \\
\text { movements, challengers } \\
\text { within the humanities and } \\
\text { social sciences }\end{array}$ & $\begin{array}{l}\text { Large corporations } \\
\text { supported by strong } \\
\text { allies, (e.g. several } \\
\text { US presidents) }\end{array}$ & $\begin{array}{l}\text { Fossil fuel industry, } \\
\text { certain scientific allies } \\
\text { (e.g. some atmospheric } \\
\text { scientists, geologists, } \\
\text { economists) }\end{array}$ & $\begin{array}{l}\text { Right-wing } \\
\text { contrarian think } \\
\text { tanks, fossil fuel } \\
\text { corporations, and } \\
\text { interest groups }\end{array}$ \\
\hline What is at stake? & $\begin{array}{l}\text { Effective governance of } \\
\text { climate change }\end{array}$ & $\begin{array}{l}\text { Scientifically informed } \\
\text { policies }\end{array}$ & $\begin{array}{l}\text { Continued profitability } \\
\text { of the fossil fuel industry } \\
\text { and infrastructure }\end{array}$ & $\begin{array}{l}\text { Achieve climate targets } \\
\text { while allowing } \mathrm{BaU}\end{array}$ & $\begin{array}{l}\text { Freedom from } \\
\text { government } \\
\text { interference in energy } \\
\text { markets }\end{array}$ \\
\hline $\begin{array}{l}\text { What are the power } \\
\text { structures? }\end{array}$ & $\begin{array}{l}\text { Strict UN principles ( } 1 \\
\text { country } 1 \text { vote) }\end{array}$ & $\begin{array}{l}\text { No hierarchies but strong } \\
\text { coalitions }\end{array}$ & $\begin{array}{l}\text { Strong hierarchies } \\
\text { and coalitions }\end{array}$ & $\begin{array}{l}\text { Coalitions with fossil } \\
\text { fuel interests }\end{array}$ & $\begin{array}{l}\text { No hierarchies, but } \\
\text { strong, often covert, } \\
\text { coalitions }\end{array}$ \\
\hline $\begin{array}{l}\text { coalitions, } \\
\text { hierarchies }\end{array}$ & $\begin{array}{l}\text { Strong coalitions and } \\
\text { vested interests }\end{array}$ & $\begin{array}{l}\text { Few very important } \\
\text { players (e.g. IPCC) }\end{array}$ & & & \\
\hline $\begin{array}{l}\text { What type of field is } \\
\text { it? }\end{array}$ & Stable & Stable and transforming & Stable and transforming & $\begin{array}{l}\text { Emerged suddenly from } \\
\text { a paper by Paul }\end{array}$ & $\begin{array}{l}\text { Emergent and } \\
\text { transforming }\end{array}$ \\
\hline $\begin{array}{l}\text { Emergent, stable, or } \\
\text { transforming }\end{array}$ & & $\begin{array}{l}\text { Shifting from a natural } \\
\text { science focus to an } \\
\text { integrated understanding }\end{array}$ & $\begin{array}{l}\text { Some firms accept } \mathrm{CC} \text {, } \\
\text { some } \\
\text { do not }\end{array}$ & $\begin{array}{l}\text { Crutzen in } 2006 \\
\text { Transformed the field } \\
\text { of CC policy: } \\
\text { geoengineering is now } \\
\text { ostensibly inevitable }\end{array}$ & \\
\hline \multirow[t]{2}{*}{$\begin{array}{l}\text { Which are the main } \\
\text { relationships } \\
\text { between fields? }\end{array}$} & $\begin{array}{l}\text { Dominant field: } \\
\text { all other fields must } \\
\text { relate to it }\end{array}$ & $\begin{array}{l}\text { Strongly aligned with CC } \\
\text { Policy Regime }\end{array}$ & $\begin{array}{l}\text { Aligned with } \mathrm{CC} \\
\text { denialism, but tries to } \\
\text { keep that hidden }\end{array}$ & $\begin{array}{l}\text { Aligned with fossil fuel } \\
\text { interests but against } \\
\text { CC denialism }\end{array}$ & $\begin{array}{l}\text { In opposition to } \mathrm{CC} \\
\text { policy and climate } \\
\text { science }\end{array}$ \\
\hline & & $\begin{array}{l}\text { Constant conflict with } \mathrm{CC} \\
\text { denialism }\end{array}$ & $\begin{array}{l}\text { Embraces } \\
\text { geoengineering as a } \\
\text { means to get support for } \\
\text { "clean" fossil fuels }\end{array}$ & $\begin{array}{l}\text { Support from certain } \\
\text { scientific interests: } \\
\text { (atmospheric science, } \\
\text { geology, macro- } \\
\text { economics, new } \\
\text { technologies) }\end{array}$ & $\begin{array}{l}\text { Inroads into CC } \\
\text { policy through } \\
\text { lobbying when } \\
\text { geoengineering } \\
\text { received scientific } \\
\text { legitimacy }\end{array}$ \\
\hline \multirow{2}{*}{$\begin{array}{l}\text { What are the social } \\
\text { skills, } \\
\text { entrepreneurial } \\
\text { actions, material } \\
\text { and discursive } \\
\text { resources? }\end{array}$} & \multirow[t]{2}{*}{$\begin{array}{l}\text { Highly structured, little } \\
\text { room for } \\
\text { entrepreneurship }\end{array}$} & $\begin{array}{l}\text { Wide range } \\
\text { of social skills }\end{array}$ & $\begin{array}{l}\text { Extremely well-funded, } \\
\text { strong discursive and } \\
\text { entrepreneurial skills }\end{array}$ & $\begin{array}{l}\text { Few high profile actors } \\
\text { - still under } \\
\text { development }\end{array}$ & $\begin{array}{l}\text { Well-funded with } \\
\text { strong discursive skills }\end{array}$ \\
\hline & & $\begin{array}{l}\text { Ambivalent support from } \\
\text { the general public }\end{array}$ & $\begin{array}{l}\text { Paint optimistic } \\
\text { scenarios of future } \\
\text { potential of CDR while } \\
\text { resisting immediate } \\
\text { mitigation }\end{array}$ & & \\
\hline \multirow{2}{*}{$\begin{array}{l}\text { Are there any } \\
\text { exogenous shocks, } \\
\text { contentions, } \\
\text { ruptures, or threats? }\end{array}$} & $\begin{array}{l}\text { Major shock and } \\
\text { rupture at COP15 }\end{array}$ & $\begin{array}{l}\text { The current US } \\
\text { administration }\left(45^{\text {th }}\right. \\
\text { president) as a shock }\end{array}$ & $\begin{array}{l}\text { Thrives under current } \\
\text { US administration }\left(45^{\text {th }}\right. \\
\text { president })\end{array}$ & $\begin{array}{l}\text { Faces opposition from } \\
\text { many varied interest } \\
\text { groups }\end{array}$ & $\begin{array}{l}\text { Thrives under current } \\
\text { US administration } \\
\left.\text { ( } 45^{\text {th }} \text { president }\right)\end{array}$ \\
\hline & & & No immediate threats & Weak social acceptance & $\begin{array}{l}\text { Under constant threat } \\
\text { from } \\
\text { CC science }\end{array}$ \\
\hline
\end{tabular}

Nobel laureates who first described how stratospheric ozone was destroyed by chemicals and whose discoveries led to the Montreal Protocol (Kaniaru 2007), often heralded as the most successful multilateral environmental treaty ever.

According to the Web of Science, in the six years that preceded Crutzen's essay, 2000-2005, only four papers containing "solar radiation management" or "albedo enhancement" were published. In the six years after Crutzen's essay, 2007-2012, 77 papers were published (January 2018). Thus, it seems clear that Crutzen's essay was instrumental in initiating the Royal Society landmark report on geoengineering in 2009 (Shepherd 2009).
Even if that report takes a very cautious approach to geoengineering, stressing the uncertainty and ethical aspects associated with it, it offered scientific legitimacy to geoengineering, which was reinforced in 2014 by the IPCC in AR 5 (IPCC 2014).

At the time of the publication of Crutzen's essay, the strategic action field of climate change mitigation (CC policy regime), i.e., reduction of emissions, was dominated by environmental interests from scientists, governments, Big International NGOs, and NGOs. Within the realm of the United Nations Framework Convention on Climate Change, governments had created an 
"array of narrowly-focused regulatory regimes - what we call the "regime complex for climate change"" (Keohane and Victor 2011). The fossil fuel industry was largely excluded from any of these mechanisms. Their interest was more oriented toward undermining the regime complex by engaging in climate denialism and aggressive lobbying (Mulvey and Shulman 2015). The emergence of geoengineering as a legitimate field in climate change discourses, legitimate because of Crutzen, the Royal Society, and the IPCC, implied that the fossil fuel sector could enter the climate change policy regime. A further implication was that interests associated with climate change denialism could suddenly make an inroad into the climate change policy regime, as seen in Figure 2. In summary, this case clearly shows how a complex web of incumbents and challengers come to interact.

Fig. 2. Schematic picture of how strategic action fields are linked and may interact with the Earth system. Numbers refer to Table 1 .

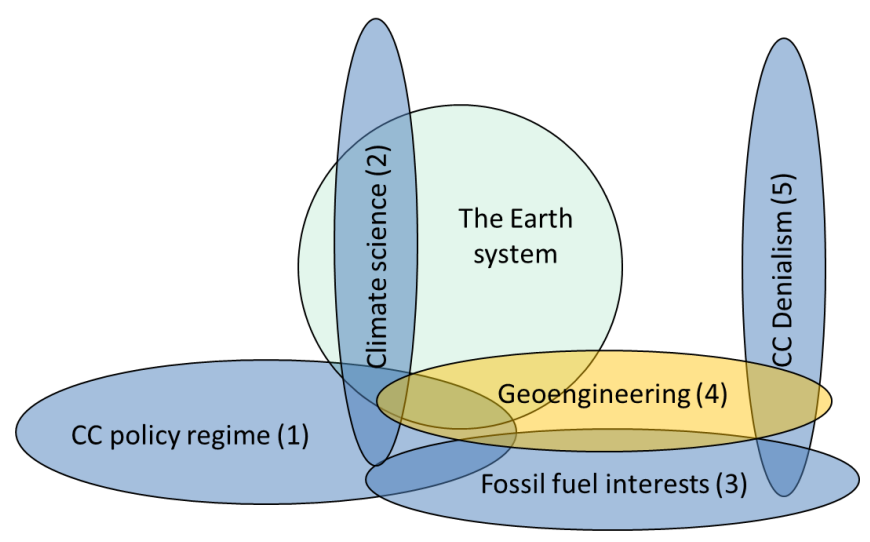

The incumbents in the climate change policy regime, such as governments, UN organizations, the IPCC, the broad scientific community, etc., are strong and hard to challenge, but co-optation can be as effective (Friedrichs 2011). The main challengers in this field are primarily the fossil fuel industry and its proponents, including some oil producing countries (Union of Concerned Scientists 2017). Their interest is not climate change per se, but the implications of climate change for the future of fossil fuel production and consumption. So, by embracing the idea of geoengineering, i.e., participating in the Geoengineering field, the fossil fuel industry can now play on yet another arena. More recently, the Trump administration in the USA created a windfall for the fossil fuel industry by opening for them the gates to policy making hubs for both energy (DOE) and the environment (EPA; Marie and Pifer 2017).

To recap the idea of a strategic action field, a strategic action field represents a social space where actors, because of dependent interests, are forced to increasingly take one another into account in their own actions and to do so from a more or less privileged position or niche. In this space, issues of power, interest, and values are at work and so are issues of meaning and identity (Fligstein and McAdam 2012). Once we understand how social relations in one strategic action field are tied to relations in others, we can start capturing the dynamics of a given field (Fligstein and
McAdam 2012). In the context of sustainability challenges, field theory is supposed to offer insights into whether or not a particular idea, policy, or project will spread and whether it will dominate the field by virtue of who is launching, defending, and/ or supporting it. The hope is that such engagement with field theory would increase the potential impact of critical problemsolving research in sustainability science.

The special characteristic of the field of climate change is the undeniable link to the Earth system. This means that all subfields must relate to unprecedented empirical evidence of climate change impacts, such as heat waves, floods, intensifying hurricane seasons, collapsing ice sheets, and disappearing sea ice. For the climate change policy regime and climate change science this increases the urgency of acting to prevent severe climate impacts. For climate change denialism it means their arguments for opposing climate change actions are weakened, while the field of geoengineering is strengthened.

\section{CONCLUSIONS}

At this point it should be clear why and how we argue for "holistic pluralism" in the effort to generate and integrate "the best available knowledge" on sustainability challenges and persistent social problems from both the natural and the social sciences. Further, and by suggesting a combined frame of social fields and natural systems including a heuristic scheme for how to use it (Table 1), we provide a fruitful approach and direction for sustainability research. In all, we have made three key contributions. First, we identified reasons for the incommensurability between the social and natural sciences, and proposed remedies for how to overcome some of the resulting difficulties in integrative research. Second, we discussed ontological, epistemological, and theoretical issues that are central in questions at the juncture between social and natural sciences. We did so to show how sustainability science and research will benefit from drawing more profoundly on, and thus more adequately incorporating, varied social science understandings of society. With that, we also set the stage for introducing field theory. Third, and importantly, in two empirical examples of high relevance for sustainability research, we illustrated the use of field theory. Through systematic identification and location of strategic action fields and a theoretically informed analysis of their internal and external interactions, be they discursive, spatial, or temporal, such research can contribute to generating the best available knowledge that enables sustainability science to go beyond cultural, economic, environmental, technical, and other determinism. As such, we have argued that a field theory approach is a fertile foundation for holistic pluralism. In practice, it means that scholars who seek to engage with this will have to be conscious of their own theoretical and methodological stance; be conscious of the advantages and disadvantages of theories and methodologies used by others; and be tolerant of this varied use (Norgaard 1989). Such endeavors are perhaps best undertaken in interdisciplinary settings that allow and embrace empirical, methodological, and theoretical diversity as well as intense communication and reflexivity.

[1] According to the French philosopher René Girard, people naturally imitate the desires of others. He calls this "mimetic desire" after the Greek word "mimesis." By Giradian economics, 
Roe referred to an economic behavior that is based on mimicking others; for further explanation see (DiMaggio and Powell 1983).

\section{AUTHOR CONTRIBUTIONS}

Lennart Olsson conceived of the idea. After that we developed, wrote, and revised the manuscript together.

Responses to this article can be read online at: http://www.ecologyandsociety.org/issues/responses. $\mathrm{php} / 10333$

\section{Acknowledgments:}

This research was undertaken within the interdisciplinary LUCID project (2008-2018) funded by the Swedish Research Council Formas through the Linnaeus grants: Lund University Centre of Excellence for integration of Social and Natural Dimensions of Sustainability (LUCID) (259-2008-1718). We are grateful to LUCID colleagues who commented on early ideas developed in this article and to those who commented on previous versions of this manuscript, in particular we would like to thank Yahia Mahmoud, Johannes Persson, and Henrik Thorén. We also appreciate the positive, constructive, and inspiring critique from two anonymous reviewers.

\section{LITERATURE CITED}

Abbott, A. 2004. Methods of discovery: heuristics for the social sciences. W. W. Norton \& Company, New York, New York, USA.

Agardy, T., P. Bridgewater, M. P. Crosby, J. Day, P. K. Dayton, R. Kenchington, D. Laffoley, P. McConney, P. A. Murray, J. E. Parks, and L. Peau. 2003. Dangerous targets? Unresolved issues and ideological clashes around marine protected areas. Aquatic Conservation: Marine and Freshwater Ecosystems 13:353-367. http://dx.doi.org/10.1002/aqc.583

Agrawal, A. 1995. Dismantling the divide between indigenous and scientific knowledge. Development and Change 26:413-439. http://dx.doi.org/10.1111/j.1467-7660.1995.tb00560.x

Allwood, J. M., V. Bosetti, N. K. Dubash, L. Gómez-Echeverri, and C. von Stechow. 2014. Glossary. Pages 1249-1274 in O. Edenhofer, R. Pichs-Madruga, Y. Sokona, E. Farahani, S. Kadner, K. Seyboth, A. Adler, I. Baum, S. Brunner, P. Eickemeier, B. Kriemann, J. Savolainen, S. Schlömer, C. von Stechow, T. Zwickel, and J. C. Minx, editors. Climate change 2014: mitigation of climate change. Working Group III Contribution to the Fifth Assessment Report of the IPCC. Cambridge University Press, Cambridge, UK.

Anderies, J. M., M. A. Janssen, and E. Ostrom. 2004. A framework to analyze the robustness of social-ecological systems from an institutional perspective. Ecology and Society 9(1):18. http://dx. doi.org/10.5751/ES-00610-090118

Anderson, B. 2015. What kind of thing is resilience? Politics 35:60-66. http://dx.doi.org/10.1111/1467-9256.12079

Baker, A. 2016. Simplicity. E. N. Zalta, editor. The Stanford encyclopedia of philosophy. Winter 2016 Edition. Metaphysics Research Lab, Stanford University, Palo Alto, California, USA.
Banerjee, S., J. Y. Gerlitz, and B. Hoermann. 2011. Labour migration as a response strategy to water hazards in the Hindu KushHimalayas. International Centre for Integrated Mountain Development (ICIMOD), Kathmandu, Nepal.

Béné, C., R. G. Wood, A. Newsham, and M. Davies. 2012. Resilience: new utopia or new tyranny? Reflection about the potentials and limits of the concept of resilience in relation to vulnerability reduction programmes. IDS Working Paper 2012 (405).

Berkes, F., C. Folke, and J. Colding. 2000. Linking social and ecological systems: management practices and social mechanisms for building resilience. Cambridge University Press, Cambridge, UK.

Bickel, J. E., and L. Lane. 2009. An analysis of climate engineering as a response to climate change. Copenhagen Consensus Center, Copenhagen, Denmark.

Blumer, H. 1986. Symbolic interactionism: perspective andmethod. University of California Press, Berkeley, California, USA.

Boda, C. 2018. The beach beneath the road: sustainable coastal development beyond governance and economics. Dissertation. Lund University, Lund, Sweden.

Bourdieu, P. 1977. Outline of a theory of practice. Cambridge University Press, Cambridge, UK. https://doi.org/10.1017/ $\underline{\mathrm{CBO} 9780511812507}$

Bourdieu, P. 1986. The forms of capital. Pages 81-93 in I. Szeman and T. Kaposy, editors. Cultural theory: an anthology. Blackwell Publishing, Chichester, UK.

Brown, K. 2014. Global environmental change I. A social turn for resilience? Progress in Human Geography 38:107-117. http:// dx.doi.org/10.1177/0309132513498837

Burawoy, M. 2009. The extended case method: four countries, four decades, four great transformations, and one theoretical tradition. University of California Press, Berkeley, California, USA.

Carolan, M. S. 2005a. Realism without reductionism: toward an ecologically embedded sociology. Human Ecology Review 12:1-20.

Carolan, M. S. 2005b. Barriers to the adoption of sustainable agriculture on rented land: an examination of contesting social fields. Rural Sociology 70:387-413.

Chandler, D. 2014. Beyond neoliberalism: resilience, the new art of governing complexity. Resilience 2:47-63. http://dx.doi. org/10.1080/21693293.2013.878544

Cherry, M. A., and J. F. Sneirson. 2010. Beyond profit: rethinking corporate social responsibility and greenwashing after the BP oil disaster. Tulane Law Review 85:983-1038. http://dx.doi. org/10.2139/ssrn.1670149

Christmann, P. 2000. Effects of "best practices" of environmental management on cost advantage: the role of complementary assets. Academy of Management Journal 43:663-680.

Clarke, S., and A. Walsh. 2009. Scientific imperialism and the proper relations between the sciences. International Studies in the Philosophy of Science 23:195-207. http://dx.doi.org/10.1080/026$\underline{98590903007170}$ 
Cole, M., P. Lindeque, C. Halsband, and T. S. Galloway. 2011. Microplastics as contaminants in the marine environment: a review. Marine Pollution Bulletin 62:2588-2597. http://dx.doi. org/10.1016/j.marpolbul.2011.09.025

Collins, R. 2004. Interaction ritual chains. Princeton University Press, Princeton, New Jersey, USA. http://dx.doi. org/10.1515/9781400851744

Cooper, M. 2011. Complexity theory after the financial crisis: the death of neoliberalism or the triumph of Hayek? Journal of Cultural Economy 4:371-385. http://dx.doi.org/10.1080/1753035$\underline{0.2011 .609692}$

Cote, M., and A. J. Nightingale. 2012. Resilience thinking meets social theory: situating social change in socio-ecological systems (SES) research. Progress in Human Geography 36:475-489. http:// dx.doi.org/10.1177/0309132511425708

Cox, R. W. 1981. Social forces, states and world orders: beyond international relations theory. Millennium 10:126-155. http://dx. doi.org/10.1177/03058298810100020501

Cretney, R., and S. Bond. 2014. 'Bouncing back' to capitalism? Grass-roots autonomous activism in shaping discourses of resilience and transformation following disaster. Resilience 2:18-31. http://dx.doi.org/10.1080/21693293.2013.872449

Crutzen, P. J. 2006. Albedo enhancement by stratospheric sulfur injections: a contribution to resolve a policy dilemma? Climatic Change 77:211-219. http://dx.doi.org/10.1007/s10584-006-9101$\mathrm{y}$

Cumming, G. S., D. H. M. Cumming, and C. L. Redman. 2006. Scale mismatches in social-ecological systems: causes, consequences, and solutions. Ecology and Society 11(1):14. http:// dx.doi.org/10.5751/ES-01569-110114

d'Albergo, E., and G. Moini. 2017. Depoliticizing public action by politicizing issues, practices and actors. The role of resilience thinking in a program of the Cariplo Foundation. Partecipazione e Conflitto 10:381-420.

Dessler, D. 1989. What's at stake in the agent-structure debate? International Organization 43:441-473. http://dx.doi.org/10.1017/ $\underline{\mathrm{S} 0020818300032999}$

Devia, G. K., B. P. Ganasri, and G. S. Dwarakish. 2015. A review on hydrological models. Aquatic Procedia 4:1001-1007. http://dx. doi.org/10.1016/j.aqpro.2015.02.126

DiMaggio, P. J., and W. W. Powell. 1983. The iron cage revisited: institutional isomorphism and collective rationality in organizational fields. American Sociological Review 48:147-160. http://dx.doi.org/10.2307/2095101

Douglas, M., and A. Wildavsky. 1983. Risk and culture: an essay on the selection of technical and environmental dangers. University of California Press, Berkeley, California, USA.

Dupre, J. 1991. Reflections on biology and culture. Pages 125-131 in J. J. Sheehan and M. Sosna, editors. Boundaries of humanity: humans, animals, machines. University of California Press, Berkeley, California, USA.

Dupre, J. 1994. Against scientific imperialism. PSA: Proceedings of the Biennial Meeting of the Philosophy of Science Association
1994(2):374-381. http://dx.doi.org/10.1086/psaprocbienmeetp.1994.2.192948

Dupré, J. 2001. Human nature and the limits of science. Oxford University Press, Oxford, UK. http://dx.doi.org/10.1093/019924$\underline{8060.001 .0001}$

Fainstein, S. 2015. Resilience and justice. International Journal of Urban and Regional Research 39:157-167. http://dx.doi. org/10.1111/1468-2427.12186

Faran, T. S., and L. Olsson. 2018. Geoengineering: neither economical, nor ethical - a risk - reward nexus analysis of carbon dioxide removal. International Environmental Agreements: Politics, Law and Economics 18:63-77. http://dx.doi.org/10.1007/ $\underline{\text { s10784-017-9383-8 }}$

Fligstein, N., and D. McAdam. 2012. A theory of fields. Oxford University Press, New York, New York, USA. http://dx.doi. org/10.1093/acprof:oso/9780199859948.001.0001

Friedrichs, J. 2011. Peak energy and climate change: the double bind of post-normal science. Futures 43:469-477. http://dx.doi. org/10.1016/j.futures.2010.12.004

Gamson, W. A. 1975. The strategy of social protest. Dorsey, Homewood, Illinois, USA.

Geels, F. W., F. Berkhout, and D. P. van Vuuren. 2016. Bridging analytical approaches for low-carbon transitions. Nature Climate Change 6:576-583. http://dx.doi.org/10.1038/nclimate2980

Giddens, A. 1979. Central problems in social theory: action, structure and contradiction in social analysis. Palgrave, London, UK. http://dx.doi.org/10.1007/978-1-349-16161-4

Gioli, G., T. Khan, S. Bisht, and J. Scheffran. 2014. Migration as an adaptation strategy and its gendered implications: a case study from the Upper Indus Basin. Mountain Research and Development 34:255-265. http://dx.doi.org/10.1659/MRD-JOURNAL-D-13-00089.1

Goldring, L. 1998. The power of status in transnational social fields. Pages 165-195 in M. P. Smith and L. E. Guarnizo, editors. Transnationalism from below. Transaction, New Brunswick, New Jersey, USA.

Guerry, A. D., S. Polasky, J. Lubchenco, R. Chaplin-Kramer, G. C. Daily, R. Griffin, M. Ruckelshaus, I. J. Bateman, A. Duraiappah, T. Elmqvist, et al. 2015. Natural capital and ecosystem services informing decisions: from promise to practice. Proceedings of the National Academy of Sciences 112:7348-7355. http://dx.doi.org/10.1073/pnas.1503751112

Harnesk, D. 2018. Adding fuel to the fire: north-south dynamics in the geographies of transport energy: the case of EU biofuels. Dissertation, Lund University, Lund, Sweden.

Hatt, K. 2013. Social attractors: a proposal to enhance "resilience thinking" about the social. Society \& Natural Resources 26:30-43. http://dx.doi.org/10.1080/08941920.2012.695859

Hay, C. 2002. Political analysis: a critical introduction. Palgrave Macmillan, Basingstoke, UK. http://dx.doi.org/10.1007/978-0-2$\underline{30-62911-0}$

Hilborn, R. 2017. Are MPAs effective? ICES Journal of Marine Science 75:1160-1162. http://dx.doi.org/10.1093/icesjms/fsx068 
Hilborn, R., and C. J. Walters. 1992. Quantitative fisheries stock assessment: choice, dynamics and uncertainty. Springer Science \& Business Media, Boston, Massachusetts, USA. http://dx.doi. org/10.1007/978-1-4615-3598-0

Holling, C. S. 2001. Understanding the complexity of economic, ecological, and social systems. Ecosystems 4:390-405. http://dx. doi.org/10.1007/s10021-001-0101-5

Horton, J. B., D. W. Keith, and M. Honegger. 2016. Implications of the Paris Agreement for carbon dioxide removal and solar geoengineering. Viewpoints. Harvard Project on Climate Agreements, Cambridge, Massachusetts, USA.

Immerzeel, W. W., L. P. H. van Beek, and M. F. P. Bierkens. 2010. Climate change will affect the Asian water towers. Science 328:1382-1385. http://dx.doi.org/10.1126/science.1183188

Intergovernmental Panel on Climate Change (IPCC). 2012. Managing the risks of extreme events and disasters to advance climate change adaptation. A special report of Working Groups I and II of the Intergovernmental Panel on Climate Change. C. B. Field, V. Barros, T. F. Stocker, D. Qin, D. J. Dokken, K. L. Ebi, M. D. Mastrandrea, K. J. Mach, G.-K. Plattner, S. K. Allen, M. Tignor, and P. M. Midgley, editors. Cambridge University Press, Cambridge, UK.

Intergovernmental Panel on Climate Change (IPCC). 2014. Climate change 2014: mitigation of climate change. Contribution of Working Group III to the Fifth Assessment Report of the Intergovernmental Panel on Climate Change. O. Edenhofer, R. Pichs-Madruga, Y. Sokona, E. Farahani, S. Kadner, K. Seyboth, A. Adler, I. Baum, S. Brunner, P. Eickemeier, B. Kriemann, J. Savolainen, S. Schlömer, C. von Stechow, T. Zwickel, and J. C. Minx, editors. Cambridge University Press, Cambridge, UK.

Ionesco, D., D. Mokhnacheva, and F. Gemenne. 2016. The atlas of environmental migration. Routledge, London, UK.

Isgren, E., A. Jerneck, and D. O'Byrne. 2017. Pluralism in search of sustainability: ethics, knowledge and methodology in sustainability science. Challenges in Sustainability 5:2-6. http://dx. doi.org/10.12924/cis2017.05010002

Jerneck, A., and L. Olsson. 2008. Adaptation and the poor: development, resilience and transition. Climate Policy 8:170-182. http://dx.doi.org/10.3763/cpol.2007.0434

Jerneck, A., and L. Olsson. 2011. Breaking out of sustainability impasses: how to apply frame analysis, reframing and transition theory to global health challenges. Environmental Innovation and Societal Transitions 1:255-271. http://dx.doi.org/10.1016/j. $\underline{\text { eist.2011.10.005 }}$

Jerneck, A., L. Olsson, B. Ness, S. Anderberg, M. Baier, E. Clark, T. Hickler, A. Hornborg, A. Kronsell, E. Lövbrand, and J. Persson. 2011. Structuring sustainability science. Sustainability Science 6:69-82. http://dx.doi.org/10.1007/s11625-010-0117-x

Jones, P., L. Bradbury, and S. LeBoutillier. 2011. Introducing social theory. Polity, Cambridge, UK.

Joseph, J. 2013. Resilience as embedded neoliberalism: a governmentality approach. Resilience 1:38-52. http://dx.doi. org/10.1080/21693293.2013.765741
Kahneman, D., and A. Tversky. 2013. Prospect theory: an analysis of decision under risk. Pages 99-127 in L. C. MacLean and W. T. Ziemba, editors. Handbook of the fundamentals of financial decision making: Part I. World Scientific, Singapore. http://dx.doi. org/10.1142/97898144173580006

Kalfagianni, A., and D. Fuchs. 2015. Private agri-food governance and the challenges for sustainability. Pages 274-290 in G. M. Robinson and D. A. Carson, editors. Handbook on the globalisation of agriculture. Edward Elgar, Cheltenham, UK. http://dx.doi.org/10.4337/9780857939838.00021

Kaniaru, D. 2007. The Montreal protocol: celebrating 20 Years of environmental progress: ozone layer and climate protection. United Nations Environment Programme/Earthprint, Nairobi, Kenya.

Kauffman, J., and S. Arico. 2014. New directions in sustainability science: promoting integration and cooperation. Sustainability Science 9:413-418. http://dx.doi.org/10.1007/s11625-014-0259-3

Kellert, S. H., H. E. Longino, and C. K. Waters. 2006. Introduction: the pluralist stance. Pages vii-xxix in S. H. Kellert, H. E. Longino, and C. K. Waters, editors. Scientific pluralism. Minnesota Studies in the Philosophy of Science Volume XIX. University of Minnesota Press, Minneapolis, Minnesota, USA.

Keohane, R. O., and D. G. Victor. 2011. The regime complex for climate change. Perspectives on Politics 9:7-23. http://dx.doi. org/10.1017/S1537592710004068

Khan, B., M. J. Iqbal, and M. A. K. Yosufzai. 2011. Flood risk assessment of river Indus of Pakistan. Arabian Journal of Geosciences 4:115-122. http://dx. doi.org/10.1007/s12517-009-0110-9

Kumar, P. 2010. The economics of ecosystems and biodiversity: ecological and economic foundations. UNEP and Earthscan, London, UK and Washington, D.C., USA.

Lane, L. 2009. Researching solar radiation management as a climate policy option. Statement before the House Committee on Science and Technology. American Enterprise Institute, Washington, D.C., USA.

Levitt, P., and N. G. Schiller. 2004. Conceptualizing simultaneity: a transnational social field perspective on society. International Migration Review 38:1002-1039. http://dx.doi.org/10.1111/ j.1747-7379.2004.tb00227.x

Lubchenco, J., and K. Grorud-Colvert. 2015. Making waves: the science and politics of ocean protection. Science 350:382-383. http://dx.doi.org/10.1126/science.aad5443

Ludwig, D., R. Hilborn, and C. Walters. 1993. Uncertainty, resource exploitation, and conservation: lessons from history. Science 260:17-36. http://dx.doi.org/10.1126/science.260.5104.17

Mahoney, J. 2000. Path dependence in historical sociology. Theory and Society 29:507-548. http://dx.doi.org/10.1023/A:1007113830879

Mahoney, J., and K. Thelen. 2010. A theory of gradual institutional change. Pages 1-37 in J. Mahoney and K. Thelen, editors. Explaining institutional change: ambiguity, agency, and power. Cambridge University Press, Cambridge, UK.

Mäki, U. 2009. Economics imperialism: concept and constraints. Philosophy of the Social Sciences 39:351-380. http://dx.doi. org/10.1177/0048393108319023 
Mäki, U. 2013. Scientific imperialism: difficulties in definition, identification, and assessment. International Studies in the Philosophy of Science 27:325-339. http://dx.doi.org/10.1080/02698595.2013.825496

Mann, M. 1986. The sources of social power: a history of power from the beginning to AD 1760, volume I. Cambridge University Press, Cambridge, UK. http://dx.doi.org/10.1017/CBO9780511570896

Mann, M. E., S. Rahmstorf, K. Kornhuber, B. A. Steinman, S. K. Miller, and D. Coumou. 2017. Influence of anthropogenic climate change on planetary wave resonance and extreme weather events. Scientific Reports 7:45242. http://dx.doi.org/10.1038/ $\underline{\text { srep } 45242}$

Marie, C., and R. Pifer. 2017. Shale Law in the spotlight: use of the Congressional Review Act to alter energy and environmental policy in the early days of the Trump Administration. Penn State Law Research Paper Series No. 9-2017. http://dx.doi.org/10.2139/ $\underline{\text { ssrn. } 2943728}$

Marshall, K. N., I. C. Kaplan, E. E. Hodgson, A. Hermann, D. S. Busch, P. McElhany, T. E. Essington, C. J. Harvey, and E. A. Fulton. 2017. Risks of ocean acidification in the California current food web and fisheries: ecosystem model projections. Global Change Biology 23:1525-1539. http://dx.doi.org/10.1111/ gcb. 13594

Martin, J. L. 2003. What is field theory? 1. American Journal of Sociology 109:1-49. http://dx.doi.org/10.1086/375201

Mckeown, A., and J. Glenn. 2018. The rise of resilience after the financial crises: a case of neoliberalism rebooted? Review of International Studies 44(2):193-214. http://dx.doi.org/10.1017/ $\underline{\text { S0260210517000493 }}$

Meadowcroft, J. 2011. Engaging with the politics of sustainability transitions. Environmental Innovation and Societal Transitions 1:70-75. http://dx.doi.org/10.1016/i.eist.2011.02.003

Midgley, M. 1984. Reductivism, fatalism and sociobiology. Journal of Applied Philosophy 1:107-114. http://dx.doi. org/10.1111/j.1468-5930.1984.tb00190.x

Mitchell, S. D. 2009. Unsimple truths: science, complexity, and policy. University of Chicago Press, Chicago, Illinois, USA. http:// dx.doi.org/10.7208/chicago/9780226532653.001.0001

Mulvey, K., and S. Shulman. 2015. The climate deception dossiers: internal fossil fuel industry memos reveal decades of corporate disinformation. Union of Concerned Scientists, Washington, D. C., USA.

Mykhnenko, V. 2016. Resilience: a right-wingers' ploy? Pages 250-267 in S. Springer, K. Birch, and J. MacLeavy, editors. Handbook of neoliberalism. Routledge, Abingdon, UK.

Nastar, M. 2014. Navigating troubled waters. Dissertation. Lund University, Lund, Sweden.

Newton, A. C. 2016. Biodiversity risks of adopting resilience as a policy goal. Conservation Letters 9(5):369-376. http://dx.doi. org/10.1111/conl.12227

Norgaard, R. B. 1989. The case for methodological pluralism. Ecological Economics 1:37-57. http://dx.doi.org/10.1016/0921-8009 (89)90023-2
Norgaard, R. B. 1994. Development betrayed: the end of progress and a co-evolutionary revisioning of the future. Routledge, London, UK.

Olsen, W. 2004. Triangulation in social research: qualitative and quantitative methods can really be mixed. Developments in Sociology 20:103-118.

Olsson, L., A. Jerneck, H. Thoren, J. Persson, and D. O'Byrne. 2015a. Why resilience is unappealing to social science: theoretical and empirical investigations of the scientific use of resilience Science Advances 1:e1400217. http://dx.doi.org/10.1126/sciadv.1400217

Olsson, L., A. Jerneck, H. Thorén, J. Persson, and D. O'Byrne. 2015b. Illustrating "why resilience is unappealing to social science." Comment on Österblom et al. Transnational corporations as 'keystone actors' in marine ecosystems. PLoS $O N E$.

Olsson, L., M. Opondo, P. Tschakert, A. Agrawal, S. H. Eriksen, S. Ma, L. N. Perch, and S. A. Zakieldeen. 2014. Livelihoods and poverty. Pages 793-832 in C. B. Field, V. R. Barros, D. J. Dokken, K. J. Mach, M. D. Mastrandrea, T. E. Bilir, M. Chatterjee, K. L. Ebi, Y. O. Estrada, R. C. Genova, B. Girma, E. S. Kissel, A. N. Levy, S. MacCracken, P. R. Mastrandrea, and L. L. White, editors. Climate change 2014: impacts, adaptation, and vulnerability. Part A: global and sectoral aspects. Contribution of Working Group II to the Fifth Assessment Report of the IPCC. Cambridge University Press, Cambridge, UK.

Österblom, H., J.-B. Jouffray, C. Folke, B. Crona, M. Troell, A. Merrie, and J. Rockström. 2015. Transnational corporations as 'keystone actors' in marine ecosystems. PLoS ONE 10:e0127533. http://dx.doi.org/10.1371/journal.pone.0127533

Ostrom, E. 2009. A general framework for analyzing sustainability of social-ecological systems. Science 325:419-422. http://dx.doi.org/10.1126/science.1172133

Parsons, M., J. Nalau, and K. Fischer. 2017. Alternative perspectives on sustainability: indigenous knowledge and methodologies. Challenges in Sustainability 5:7-14. http://dx.doi. org/10.12924/cis2017.05010007

Pauly, D., R. Hilborn, and T. A. Branch. 2013. Fisheries: Does catch reflect abundance? Nature 494:303-306. http://dx.doi. org/10.1038/494303a

Peterson, R. W. 1979. Holistic pluralism and the environmental movement. BioScience 29:399. http://dx.doi.org/10.1093/ bioscience/29.7.399

Rajbhandari, R., A. B. Shrestha, A. Kulkarni, S. K. Patwardhan, and S. R. Bajracharya. 2015. Projected changes in climate over the Indus river basin using a high resolution regional climate model (PRECIS). Climate Dynamics 44:339-357. http://dx.doi. org/10.1007/s00382-014-2183-8

Reiss, H., G. Hoarau, M. Dickey-Collas, and W. J. Wolff. 2009. Genetic population structure of marine fish: mismatch between biological and fisheries management units. Fish and Fisheries 10:361-395. http://dx.doi.org/10.1111/j.1467-2979.2008.00324.x

Ritzer, G. 2011. Sociological theory. McGraw-Hill, New York, New York, USA. 
Roe, E. 1998. Taking complexity seriously: policy analysis, triangulation and sustainable development. Springer Science \& Business Media, New York, New York, USA. http://dx.doi. org/10.1007/978-1-4615-5497-4

Rogelj, J., M. den Elzen, N. Höhne, T. Fransen, H. Fekete, H. Winkler, R. Schaeffer, F. Sha, K. Riahi, and M. Meinshausen. 2016. Paris Agreement climate proposals need a boost to keep warming well below $2{ }^{\circ} \mathrm{C}$. Nature 534:631-639. http://dx.doi. org/10.1038/nature18307

Rogelj, J., G. Luderer, R. C. Pietzcker, E. Kriegler, M. Schaeffer, V. Krey, and K. Riahi. 2015. Energy system transformations for limiting end-of-century warming to below $1.5^{\circ} \mathrm{C}$. Nature Climate Change 5:519-527. http://dx.doi.org/10.1038/nclimate2572

Rosa, E. A. 1998. Metatheoretical foundations for post-normal risk. Journal of Risk Research 1:15-44. http://dx.doi. org/10.1080/136698798377303

Sala, S., F. Farioli, and A. Zamagni. 2013. Progress in sustainability science: lessons learnt from current methodologies for sustainability assessment: Part 1. International Journal of Life Cycle Assessment 18:1653-1672. http://dx.doi.org/10.1007/ $\underline{\text { s11367-012-0508-6 }}$

Sankey, H. 2000. Kuhn's ontological relativism. Science \& Education 9:59-75. http://dx.doi.org/10.1023/A:1008662817362

Schiller, N. G. 2005. Transnational social fields and imperialism: bringing a theory of power to transnational studies. Anthropological Theory 5:439-461. http://dx.doi. org/10.1177/1463499605059231

Schiller, N. G., L. Basch, and C. Blanc-Szanton. 1992. Towards a definition of transnationalism. Annals of the New York Academy of Sciences 645(1):ix-xiv. http://dx.doi.org/10.1111/j.1749-6632.1992. $\underline{\text { tb33482.x }}$

Schleussner, C.-F., J. Rogelj, M. Schaeffer, T. Lissner, R. Licker, E. M. Fischer, R. Knutti, A. Levermann, K. Frieler, and W. Hare. 2016. Science and policy characteristics of the Paris Agreement temperature goal. Nature Climate Change 6:827-835. http://dx. doi.org/10.1038/nclimate3096

Schlüter, M., R. R. J. McAllister, R. Arlinghaus, N. Bunnefeld, K. Eisenack, F. Hölker, E. J. Milner-Gulland, B. Müller, E. Nicholson, M. Quaas, and M. Stöven. 2012. New horizons for managing the environment: a review of coupled social-ecological systems modeling. Natural Resource Modeling 25:219-272. http:// dx.doi.org/10.1111/j.1939-7445.2011.00108.x

Schmidt, V. A. 2008. Discursive institutionalism: the explanatory power of ideas and discourse. Annual Review of Political Science 11:303-326. http://dx.doi.org/10.1146/annurev.polisci.11.060606.135342

Schmidtko, S., L. Stramma, and M. Visbeck. 2017. Decline in global oceanic oxygen content during the past five decades. Nature 542:335-339. http://dx.doi.org/10.1038/nature21399

Schneider, S. H. 2001. Earth systems engineering and management. Nature 409:417-421. http://dx.doi.org/10.1038/35053203

Scott, W. R. 1995. Institutions and organizations. Sage, Thousand Oaks, California, USA.
Secor, D. H. 2014. The unit stock concept: bounded fish and fisheries. Pages 7-28 in S. X. Cadrin, L. A. Kerr, and S. Mariani, editors. Stock identification methods: applications in fishery science. Academic, London, UK. http://dx.doi.org/10.1016/ B978-0-12-397003-9.00002-3

Shepherd, J. G. 2009. Geoengineering the climate: science, governance and uncertainty. The Royal Society, London, UK.

Sparre, P., and S. C. Venema. 1998. Introduction to tropical fish stock assessment-Part 1: Manual. Food and Agriculture Organization, Rome, Italy.

Teller, E. 1997. The planet needs a sunscreen. Wall Street Journal, 17 October.

Thaler, R. H. 2016. Behavioral economics: past, present, and future. American Economic Review 106:1577-1600. http://dx.doi. org/10.1257/aer.106.7.1577

Thomasson, A. 2016. Categories. E. N. Zalta, editor. The Stanford Encyclopedia of Philosophy. Spring 2018 Edition. Metaphysics Research Lab, Stanford University, Palo Alto, California, USA.

Thorén, H. 2015. The hammer and the nail: interdisciplinarity and problem solving in sustainability science. Dissertation. Department of Philosophy, Lund University, Lund, Sweden.

Tierney, K. 2015. Resilience and the neoliberal project: discourses, critiques, practices - and Katrina. American Behavioral Scientist 59:1327-1342. http://dx.doi.org/10.1177/0002764215591187

Union of Concerned Scientists. 2017. Global warming skeptic organizations. Union of Concerned Scientists, Cambridge, Massachusetts, USA.

United Nations Framework Convention on Climate Change (UNFCCC). 2015. The Paris Agreement. UNFCCC, Paris, France.

van de Pas, R., M. Ashour, A. Kapilashrami, and S. Fustukian. 2017. Interrogating resilience in health systems development. Health Policy and Planning 32:iii88-iii90. http://dx.doi. org/10.1093/heapol/czx110

Vaughan, N. E., and T. M. Lenton. 2011. A review of climate geoengineering proposals. Climatic Change 109:745-790. http:// dx.doi.org/10.1007/s10584-011-0027-7

Verweij, M., M. Douglas, R. Ellis, C. Engel, F. Hendriks, S. Lohmann, S. Ney, S. Rayner, and M. Thompson. 2006. Clumsy solutions for a complex world: the case of climate change. Public Administration 84:817-843. http://dx.doi.org/10.1111/ j.1540-8159.2005.09566.x-i1

Walker, B., C. S. Holling, S. R. Carpenter, and A. Kinzig. 2004. Resilience, adaptability and transformability in social-ecological systems. Ecology and Society 9(2):5. http://dx.doi.org/10.5751/ ES-00650-090205

Walker, B. H., L. H. Gunderson, A. P. Kinzig, C. Folke, S. R. Carpenter, and L. Schultz. 2006. A handful of heuristics and some propositions for understanding resilience in social-ecological systems. Ecology and Society 11(1):13. http://dx.doi.org/10.5751/ ES-01530-110113 
Walsh, J. R., S. R. Carpenter, and M. J. Vander Zanden. 2016. Invasive species triggers a massive loss of ecosystem services through a trophic cascade. Proceedings of the National Academy of Sciences 113:4081-4085. http://dx.doi.org/10.1073/pnas.1600366113

Wellstead, A., M. Howlett, and J. Rayner. 2017. Structuralfunctionalism redux: adaptation to climate change and the challenge of a science-driven policy agenda. Critical Policy Studies 11(4):391-410. http://dx.doi.org/10.1080/19460171.2016.1166972 